fibroblasts, we distinguished the roughness of the cell surface quantitatively as the index of sorting. The selected cells with smooth surface (roughness index not more than 1.1) for cardiomyocytes, and confirmed that the more than $80 \%$ of the collected and recultivated cells were self-beating and the $99.2 \%$ of them were identified as cardiomyocytes by immunostaining. The results indicates the potential of the label-free cell purification using imaging cell sorting system, especially for cardiomyocytes by the index of their cell surface roughness, which might be applicable for purification of cariomyocytes for regenerative medicine.

\section{PS050 マイクロ波照射下での維生物培䈍とプロテオーム解析}

Microorganism cultivation under microwave irradiation and its proteomic analysis

Wataru Nagayoshi ${ }^{1}$, Rintaro Hoshino', Yuki Kurita ${ }^{1}$, Arata Shiraishi ${ }^{1}$, Takeo Yoshimura $^{2}$, Toru Kodama ${ }^{3}$, Shokichi Ohuchi ${ }^{1}\left({ }^{1}\right.$ Dept. Biosci. Bioinform., Kyushu Inst. Technol., ${ }^{2}$ Dept. Appl. Bio. Sci., Tokyo Univ. Sci., ${ }^{3}$ Vecell Inc.)

We have studied to take advantage of the microwave heating to the field of chemical biology and biotechnology. In this study, we applied the microwave irradiation for microorganism cultivation. The bacteria such as Escherichia coli, Flavobacteria, and Bacillus subtilis were cultivated on various temperatures and microwave irradiations. The microwave culture system was composed of multimode microwave apparatus with electrical transformer, thermocouple, and air pump. The microwave apparatus by modified domestic microwave oven could be controlled the temperature by thermocouple at $2.45 \mathrm{GHz}$ frequency. The air bubble was flowed to the culture medium instead of shaking the tube Escherichia coli JM 109 was cultured at 37 degree C for 12 hours under microwave irradiation in LB and M9 culture media. Conventional culture with bubbling was incubated by water bath at 37 degree $C$. The culture medium was sampled to measure the optical density (OD660) at each time. A comparison of optical density between conventional and microwave cultivation showed that optical density remained unchanged. On the other hand, the expressed protein from cells of E. coli JM 109 was estimated by two-dimensional electrophoresis through the treatment for the proteomic analysis. As the results, several proteins under microwave cultivation were very different from conventional incubation. Their proteins from microwave culture was analyzed and identified by method of peptide mass fingerprint (PMF)

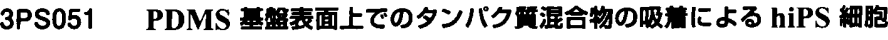 のパターニング}

Patterning for human iPS cells by adsorption mixture of proteins on PDMS surface

Ryotaro Yamada ${ }^{1}$, Koji Hattori ${ }^{2}$, Shinji Sugiura ${ }^{2}$, Toshiyuki Kanamori ${ }^{2}$, Kiyoshi Ohnuma ${ }^{1}{ }^{1}$ Nagaoka University of Technology, ${ }^{2}$ Agency of Industrial Science and Technology)

Human induced pluripotent stem (hiPS) cells derived from human somatic cells have pluripotency, and they are therefore expected to be a suitable model for studying early development. Cell differentiation is affected by cell-cell interaction, which is difficult to control. A micro-patterning technique makes it possible to create cell patterns in order to control cell-cell interaction. However, fabrication of these micro-patterns generally requires a lot of time and labor, as well as expensive reagents and robotics. Here we report a simple micropatterning technique to create patterns of hiPS cells on a polydimethylsiloxane (PDMS) surface under a serum- and feeder-free culture condition. PDMS has translucency, gas permeability, low cytotoxicity, and can be molded easily, so it is therefore typically used as a substrate material for fabricating micro structures for cell cultures. We found that cell adhesion patterning was achieved by coating a mixture of proteins, rather than a single purified protein, on a PDMS patterned surface. This suggests the cell adhesion on a PDMS surface is controlled by multiple proteins. We coated the PDMS surfaces with a combination of purified proteins and succeeded in controlling hiPS cell adhesion. We will apply this coating on a PDMS surface treated with patterned plasma. This technique enables simple and low-cost patterning of hiPS cells

\section{PT001 猃用的ストレス下での 100S リボソーム形成による細菌の生存戦略}

Survival strategy of bacteria under the starvation stress by 100 S ribosome formation

Takayuki Kato', Masami Ueta ${ }^{2}$, Tomoko Miyata', Hideji Yoshida ${ }^{3}$, Akira Wada ${ }^{3}$, Keiichi Namba ${ }^{1}\left({ }^{1}\right.$ Grad. Sch. of Frontier Biosci Osaka Univ, ${ }^{2}$ Yoshida Biol. Lab., ${ }^{3}$ Dept. Phys., Osaka Med. Coll.)

In most bacteria, protein biosynthesis is suppressed by the formation of $100 \mathrm{~S}$ ribosome, a dimmer of $70 \mathrm{~S}$ ribosome, under the starvation stress. In the case of gram-negative bacteria, such as Escherichia coli (E. coli), the $100 \mathrm{~S}$ ribosome is promoted by ribosome modulation factor (RMF) and hibernation promoting factor (HPF) binding to $70 \mathrm{~S}$ ribosome. On the other hand, a protein named SaHPF, which is a homolog of HPF, causes the formation of $100 \mathrm{~S}$ ribosome in gram-positive bacteria, such as Staphylococcus aureus (S. aureus). To understand the suppression mechanisms of protein biosynthesis, we tried to analyze both structures by cryoEM image analysis. The numbers of particle images used for the structural analyses of $100 \mathrm{~S}$ ribosome from E. coli and S. aureus were 11,889 and 15,885 , respectively. We treated the images of two $70 \mathrm{~S}$ ribosome particles individually for $3 \mathrm{D}$ image reconstruction, and the structures of $70 \mathrm{~S}$ ribosome were solved at $18 \AA$ and $15 \AA$, respectively. Then the atomic model of $70 \mathrm{~S}$ ribosome was fitted into the $3 \mathrm{D}$ density map to build the models of $100 \mathrm{~S}$ ribosomes. In both cases, $100 \mathrm{~S}$ ribosome is formed by the face-to-face contacts between the $30 \mathrm{~S}$ subunits of the two $70 \mathrm{~S}$ ribosomes. Surprisingly, however, the binding interfaces are completely different between E. coli and S. aureus. We are now trying to determine the binding site and the structure of $\mathrm{SaHPF}$ on ribosome. I will discuss different mechanisms of $100 \mathrm{~S}$ ribosome formation and the structural difference between RMF/HPF and SaHPF responsible for the different mechanisms.

\section{PT002 ラミノパチー発症に関する A 型ラミンの構造学的研究}

Electron microscopy of oligomerization function of nuclear lamin $A$ and the laminopathic mutants

Kazuhiro Mio ${ }^{1}$, Toshihiko Sugiki ${ }^{2}$, Muneyo Mio', Chie Matsuda', Yukiko Hayashi ${ }^{3}\left({ }^{1}\right.$ AIST, ${ }^{2}$ Dep. Pharm, Musashino Univ., ${ }^{3}$ NCNP)

The nuclear lamins are type $\mathrm{V}$ intermediate filament proteins that constitute lamina at the inner nuclear membrane, critically important for the structural properties of the nucleus. Mutations in A-type lamins (LMNA) cause a variety of diseases from muscular dystrophy and lipodystrophy to systemic diseases such as premature aging syndromes. The molecular basis of these diseases is still unknown. To understand the lamin-associated network at the inner nuclear membrane and the mechanisms of laminopathies onset, we analyzed the structures of lamin A ant its mutants using electron microscopy and other structure determining methods. We obtained wild type and mutant lamin A, that include R453W (Emery-Dreifuss muscular dystrophy; EDMD), R527P (EDMD) and R527H (mandibuloacral dysplasia; MAD) from recombinantly expressed E. Coli and analyzed their oligomerization function in terms of headto-tail filamentous assembly and the paracrystal formation. NMR and biochemical analysis was performed for addressing the association modification of lamin A with LEM family proteins (Lap2, EMD, Man1).

\section{PT003ＮMR 法による APOBEC3C デアミネース活性に関する研究}

\section{A study on deaminase activity of APOBEC3C by NMR}

Ryo Iwaoka ${ }^{1}$, Shingo Kitamura ${ }^{2,3}$, Keisuke Kanba', Ayako Furukawa ${ }^{1}$, Hideyasu Okamura', Wataru Sugiura ${ }^{2,4}$, Takashi Nagata', Yasumasa Iwatani $^{2,4}$, Masato Katahira ${ }^{1}$ ( ${ }^{1}$ Inst. Of Adv. Energy, Kyoto Univ., ${ }^{2} C R C$, NMC, ${ }^{3}$ Biotech., Grad. Sch. Of Eng., Nagoya Univ., ${ }^{4}$ Prog. In Integ. Mol. Med., Grad. Sch. Of Med., Nagoya Univ.)

APOBEC3 (A3) proteins are responsible for the restriction of exogenous viruses by its cytidine deaminase activity against minus strand DNA produced by reverse transcription of the virus genome. We have been focusing on $\mathrm{A} 3 \mathrm{G}$, a potent restrictor against HIV-1, and been analyzing its deaminase activity. Recently, we started analyzing cytidine deamination by $\mathrm{A} 3 \mathrm{C}$, another antiviral protein, which has different target with $\mathrm{A} 3 \mathrm{G}$. A3G prefers 5'-CCC-3' context on viral minus strand DNA, while $\mathrm{A} 3 \mathrm{C}$ primarily recognizes 5' -TC-3' context. Detailed knowledge on the molecular mechanism of the deaminase activity of A3C together with that of A3G would contribute to better understanding of how A3 family proteins recognize and catalyze the different targets.

In this study, we have applied our established NMR method (EMBO J., 2009) to monitor the time-course of cytidine deamination by $\mathrm{A} 3 \mathrm{C}$. The length of the substrate single-strand DNA (ssDNA) reportedly affects the affinity and activity of $\mathrm{A} 3 \mathrm{G}$. A3G shows similar affinity against 10-mer and longer ssDNAs, however the affinity reduces against shorter ssDNAs. In addition, the activity of A3G is highly influenced by the neighboring nucleotides of the 5'-CCC-3'. Accordingly, we have carefully designed and synthesized two 11-mer ssDNAs, TTTTTCTTTTT and AAAATCAAAAA. Using these substrates, we have chased, respectively, the decreasing and increasing signals of cytidine and uridine with time. The comparison of the deaminase activity between $\mathrm{A} 3 \mathrm{C}$ and A3G will be discussed. 